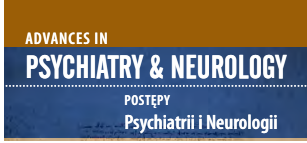

Correspondence to/Adres do korespondencji:

Angelika Kleszczewska-Albińska

Instytut Psychologii

Uniwersytet Opolski

Pl. Staszica 1

45-052 Opole, Polska

e-mail: akleszczewska@uni.opole.pl

Submitted/Otrzymano: 30.01.2021

Accepted/Przyjęto do druku: 04.05.2021

\section{The functioning of adolescents during quarantine - the role of non-professional and professional support in overcoming the problem of social isolation Funkcjonowanie nastolatków podczas kwarantanny - rola nieprofesjonalnego i profesjonalnego wsparcia w przezwyciężaniu problemu izolacji społecznej}

\author{
Angelika Kleszczewska-Albińska \\ Instytut Psychologii, Uniwersytet Opolski, Opole, Polska
}

\begin{abstract}
Purpose: The main aim of the article is to discuss common concepts about the role of non-professional and professional support offered to teenagers during social isolation due to COVID-19 pandemic. A short description of various activities that could be offered by parents, teachers, resilient peers and psychologists are given. Some information on teenage resilience is presented. The information is discussed in the developmental context, including the main biological, environmental, and social problems revealed in teenage functioning during the pandemic.

Views: The COVID-19 pandemic heavily modified the social life of teenagers, and changed their daily lives. Young people were abruptly withdrawn from schools and outdoor activities. In effect, they were faced with uncertainty and alienation, which led to decreased levels of well-being and an increase in psychological problems. Some teenagers report feeling as well as they felt before the pandemic, or report a higher level of well-being than they experienced prior to period of social isolation. Discussion on the topic of resilience is therefore needed. Adolescents, more than any other age group, need social interactions with peers, time spent outdoors, and face-to-face communication with others. The lack of these thing, accompanied by stress, leads to many mental health problems, including depression, anxiety, and changes in daily activity. Teenagers put a lot of effort to resisting these, but since the tentative social conditions continue, the damage to their mental functioning increases.

Conclusions: Raising awareness and discussing these issues is crucial, in order to alert the public health system about the mental health needs of adolescents during the pandemic.
\end{abstract}

Key words: psychotherapy, stress, mental health, adolescents, social isolation.

\title{
Streszczenie
}

Cel: Podstawowym celem artykułu jest analiza powszechnie prezentowanych koncepcji na temat roli, jaką odgrywa nieprofesjonalne i profesjonalne wsparcie oferowane nastolatkom w czasie pandemii koronawirusa (COVID-19). Przedstawiono krótki opis działań, które mogą być oferowane adolescentom przez rodziców, nauczycieli, rezylientnych rówieśników i psychologów. Całość zagadnienia omówiona została w świetle danych na temat okresu dorastania, włączając w to podstawowe biologiczne, środowiskowe i społeczne problemy obserwowane w funkcjonowaniu nastolatków podczas pandemii.

Poglądy: COVID-19 poważnie zmodyfikował funkcjonowanie społeczne nastolatków i bezprecedensowo zmienił ich codzienne życie. Młodzi ludzie zostali nagle wycofani ze szkół i aktywności na zewnątrz. W rezultacie musieli zmierzyć się z ogromną niepewnością i zmianami, które doprowadziły do spadku poziomu jakości życia i wzrostu natężenia problemów psychologicznych. W tym samym czasie część nastolatków deklaruje tak samo wysoki poziom jakości życia jak przed pandemią albo wręcz ocenia jakość swojego życia jako wyższą niż przed okresem społecznej izolacji. W świetle jakości życia psychicznego nastolatków w czasie pandemii potrzebna jest zatem dyskusja dotycząca rezyliencji. Nastolatki, bardziej niż jakakolwiek inna grupa wiekowa, potrzebuja interakcji społecznych z rówieśnikami, czasu spędzonego na zewnątrz i komunikacji twarzą w twarz. Niespełnienie tych potrzeb i współtowarzyszący im stres prowadzą do pojawienia się problemów psychicznych, włączając depresję, lęki i zmiany w codziennej 
The functioning of adolescents during quarantine - the role of non-professional and professional support in overcoming the problem of social isolation

Funkcjonowanie nastolatków podczas kwarantanny - rola nieprofesjonalnego i profesjonalnego wsparcia w przezwyciężaniu problemu izolacji społecznej

aktywności. Nastolatki wkładają wiele wysiłku w poradzenie sobie, ale z uwagi na utrzymywanie się trudnych warunków narasta poziom trudności w ich funkcjonowaniu.

Wnioski: Istotne jest podjęcie dyskusji i zaalarmowanie systemu opieki zdrowotnej w zakresie potrzeb psychicznych nastolatków funkcjonujących w czasie pandemii.

Słowa kluczowe: psychoterapia, stres, zdrowie psychiczne, adolescenci, izolacja społeczna.

\section{INTRODUCTION}

The unexpected and drastic changes in everyday life and routines caused by the rapid spread of Severe Acute Respiratory Syndrome Coronavirus 2 (SARS-CoV-2) influenced the way people were able to function socially, and abruptly modified the hitherto prevailing patterns of life. The effects of the 2019 COVID-19 pandemic are not only connected directly to the health of individuals, but also indirectly to other aspects of life. COVID-19 impacted the social, emotional, and mental well-being of people around the world. The worldwide spread of a previously unknown disease caused many challenges. It led to changes in everyday routines, breaking the continuity of both learning and health care. It was responsible for the loss of celebrations of significant life events (such as graduations), as well as of feelings of security and safety. The long-term impact of social, emotional, and mental problems accompanying COVID-19 are yet to be fully understood, but as current research shows, COVID-19 greatly influences the lives of people in different age groups $[1,2]$. Researchers underline the fact that individuals suffer from elevated levels of anxiety, depression, and posttraumatic symptoms. Increased levels of sadness, helplessness, loneliness, and nervousness are also observed. Heightened levels of suicidal thoughts and suicide attempts have also been noted [3]. Nevertheless, while most reports emphasize the rapid increase in the number of mental health- related problems during the pandemic, there is a growing amount of literature stating that some people have retained a relatively stable sense of wellbeing [4-6]. Despite the fact there are many idiosyncratic facets of these unpredicted experiences for individuals of different ages, it seems crucial to observe and analyze the functioning of adolescents over this period.

As research shows, COVID-19 infection itself may be less devastating for teenagers than it is for adults; but the side effects generated by the pandemic are very destructive for some of the representatives of this age group. At the same time, some researchers have observed that there is a significant group of resilient adolescents, reporting a high level of well-being [6, 7]. This said, the disruption of everyday life, accompanied by biopsychological stressors, may lead to serious consequences for the mental health of adolescents. Recent studies have revealed a high prevalence of depression, anxiety, psychological distress, helplessness, inattention, and irritability in a group of people under 18 years of age [8]. Additionally, problems with mental health during adolescence may impede or harm brain development, since it is more susceptible to stressors during this time of ontogenesis $[9,10]$. Special attention should be paid to teenagers who had mental problems prior to the pandemic, as the disruption of daily routines may led to an increase in the severity of their symptoms. Then again, despite the pandemic restrictions some adolescents are functioning quite well, remaining in stable peer relationships, handling stressful situations well, and reporting high levels of self-esteem [7]. It is therefore important to analyze and describe the differences between the two groups - those having problems coping with pandemic conditions and those who function well in them. This is crucial if we are to initiate a reflexive discussion on these matters, including developmental issues, and the biological, environmental, and social problems observed in the functioning of adolescents. It is essential to emphasize some basic ideas for the mental health support that should be provided for the population under 18 years of age at this time.

\section{DEVELOPMENTAL ASPECTS OF ADOLESCENCE}

Among the most vital changes observed during adolescence there are neuronal transitions, psychological development and social transformations. The importance of the appearance of social-affective development during this period is underlined in the literature. Neuronal alterations, linked to hormonal changes, occur mostly in the limbic system and pre-frontal cortex. Adolescence is considered as a time of remarkable neural plasticity, during which the brain regions involved in social cognition, and emotional reactivity and emotion regulation change significantly [11]. Young people develop strong reasoning skills, and logical and moral thinking. Gray matter decreases while white matter increases, mostly due to the myelination of axons [12]. A progressive development of executive functions, theory of mind improvement, and growth of empathy are recognized $[13,14]$.

It is believed that the fundamental reorganization of the brain that takes place during adolescence is mostly 
connected to external factors such as society, social values, responsibilities, and relationships [15]. During this period young people experiment with different roles while looking for their own identity. It is understood that this is a sensitive period for social behavior, during which teenagers are hyper-sensitive to social stimuli, and to the negative impact of any type of social exclusion [16]. Teenagers are more likely to achieve a well-defined sense of self when they have an opportunity to engage in discussions and are encouraged to make an autonomic choices [17]. In order to develop stable self-esteem, adolescents need to immerse themselves in interactions with parents and peers. Young people seek advice and embrace their parents' values, but at the same time look for the approval of their peers $[18,19]$. Adolescents spend more time with their peers than with their family members. They form complex peer and romantic relationships, and pay more attention to the social approval of others. Therefore, it is important for teenagers to stay in touch not only with parents or other adults, but with people their own age as well. In this way they achieve a greater opportunity to develop the sense of responsibility and independence they need [20].

The COVID-19 pandemic changed the life of teenagers drastically. It constrained most of their face-to-face social interactions and activities with peers, and narrowed life to within the limits of their households. It exacerbated the already-existing problems of many adolescents and introduced the new ones in the areas of neurological development, environmental functioning, and social life.

\section{TEENAGE PSYCHOSOCIAL PROBLEMS DURING SOCIAL ISOLATION}

There is evidence of harmful effects of social isolation and quarantine on the development of psychiatric disorders $[21,22]$ and the dysregulation of neuroendocrine-immune interactions [23] in group of children and adolescents. Among the direct psychological consequences of isolation due to COVID-19 are anxiety, panic, obsessive-compulsive symptoms, insomnia, digestive problems, depressive symptoms, and post-traumatic stress [24]. Prolonged social isolation may lead to longterm psychiatric symptoms, disrupt the development of personal identity, distort biopsychological balance, produce feelings of disconnection, and lead to impairments in cognitive functioning and physical health. A feeling of loneliness resulting from social isolation may generate irritability, negative self-related thoughts, and feelings of emptiness, sadness and shame [25]. Isolation from peers may disrupt social dynamic characteristic for adolescence, impede completion of developmental processes, and cause boredom, frustration, and nervousness [26].

Adolescence is considered to be a time of profound social transformation and sensitive period for social de- velopment. During this developmental stage the brain networks involved in social perception and cognition develop substantially $[27,28]$. The healthy development of teenagers requires involvement in social interactions with peers. Among the risk factors for the development of affective disorders we find loneliness, poor relationships, and problems with peers [29]. Conversely, high-quality peer relationships are considered a protective factor strengthening adolescent's resilience [30].

There are no reports on the effects of experimentally induced social isolation in groups of adolescents. The information concerning the effects of social deprivation due to COVID-19 in this age group are also limited. At the same time, there are a small number of papers on the psychological effects of social isolation due to incarceration, experimentally induced isolation in adults, and some on the effects of profound social isolation in young rodents. Research on the effects of incarceration shows that solitary confinement leads to increased distress, depression, and aggression (especially toward the self). The abovementioned effects are stronger for adolescent prisoners than for adult ones [31]. Experimentally induced acute isolation in adults leads to an increased feeling of loneliness, decreased happiness, and craving for social contact. The neuronal image of the effects of confinement is similar to that of the effects produced by food deprivation [32]. The results of animal studies on the effects of social deprivation show drastic changes in the behavior of rodents (hyper-activity, aggression), diminished cognitive performance (especially in the area of learning and attention), and dysregulation in brain neurochemical functioning (dopamine, and serotonin secretion). The up-to-date results of studies on the effects of social isolation imply that its consequences may be serious and long-lasting, and also suggest that the negative effects of social deprivation resemble the symptoms of neuropsychiatric disorders [33]. It is therefore important to extend the social contacts of adolescents beyond face-to-face communication with family members living in the same household, and to support young people through obligatory social isolation.

\section{TEENAGE RESILIENCE DURING THE COVID-19 PANDEMIC}

There is a growing amount of research proving it is possible to overcome the consequences of the internalizing and externalizing difficulties, stress, and adversities associated with the pandemic $[7,34]$. The ability to adapt to stressful situations and to overcome adversities while remaining in relatively good health is connected to resilience. Among the factors responsible for adolescent resilience, we find environmental, genetic, and epigenetic components. Researchers underline the fact that 
The functioning of adolescents during quarantine - the role of non-professional and professional support in overcoming the problem of social isolation

Funkcjonowanie nastolatków podczas kwarantanny - rola nieprofesjonalnego i profesjonalnego wsparcia w przezwyciężaniu problemu izolacji społecznej

resilience should not be considered as stable characteristic, but rather as malleable and amenable to bolstering elements [35]. Resilient teenagers report having good quality relationships with their family members, and with their friends [36]. Resilience is considered as a result of an engagement in close relationships with adults and peers, and as an effect of involvement in activities offered by schools and communities, where a person receives an opportunity to succeed and to prove their own effectiveness. Since resilience is considered a capacity to skillfully handle stressful situations, some exposure to challenging situations is also needed in order to develop this characteristic. Adolescents who have remained in stable peer relationships despite their social isolation, and those involved in hobbies, expanding their knowledge or developing their talents report greater levels of resilience [34]. Additionally, young people characterized by a high level of optimism and an elevated level of intrinsic curiosity cope well with the pandemic, and report lower levels of anxiety and depressive symptoms [37].

\section{SUPPORT FOR ADOLESCENTS SUFFERING FROM SOCIAL ISOLATION}

During adolescence young people are highly attuned to diverse relationships, and peer groups. They present amplified energy, curiosity, and openness to novelty. It is hard for teenagers to isolate at home. They report feelings of frustration, nervousness, disconnection and boredom due to social distancing restrictions. Since adolescents currently spend most of their time at home it is important to provide them with necessary support coming from non-professionals and/or professional helpers. The group of non-professional assistants consists mostly of parents, teachers, and peers, while among professional helpers there are psychiatrists, psychologists, and social workers. As young people during pandemic spend most of their time at home, with their parents, in the first place one should expect teenagers' caregivers to get involved in actions reinforcing their resilience. Parents should help their teenage offspring to plan and organize several regular activities taking place at a similar time each day. It is crucial to encourage adolescents to spend some time outdoors every day, and to get involved in some kind of physical activity. A regular sleep schedule might also increase the quality of teenage life. Some harmful effects of social exclusion can be reduced through virtual forms of communication. It is therefore essential to provide the necessary technical equipment and to encourage teenagers to engage in directed communication or to post straight to another person instead of writing to a whole group. It is also crucial to advise adolescents not to engage in the passive use of social media, since it negatively influences well-being and increases social comparisons and envy [38]. It is worth emphasizing the fact that, according to some researchers [39], the most important responsibility of teenagers' caregivers is to help them advocate for themselves and take greater responsibility for their schoolwork. In order to increase adolescents' feeling of responsibility, encouraging them to create an individual plan for schoolwork is recommended.

Teachers working with adolescents could also serve as help providers [40, 41]. It is necessary for young people to underline the importance of their peer relationships and connections. Teachers could therefore encourage their teenage students to work in pairs or in small groups in order to extend the everyday social connections of young people. Forming online versions of interest-based clubs might also be helpful in creating stable alliances between students. Establishing stable routines and schedules including built-in time for socialization, and incorporating social media as a tool for these activities, may serve as a partial substitute for face-to-face interactions. The supportive role of teachers includes providing opportunities for boosting feelings of competence [42]. This could be achieved through clear communication and elucidated expectations and standards, accompanied by the ensuring of the necessary support. Providing young people with opportunities to help others, and letting them know they prepare valuable work, may help adolescents to feel respected. It could also increase their feelings of autonomy and control over the things they are engaged in $[43,44]$.

Another important source of support for young people comes from their resilient peers. It is argued that peer support helps to improve mental health mostly by increasing an individual's effectiveness and lowering their level of stress [45]. Social contact with people immersed in a similar reality and experiencing comparable difficulties may help overcome perceived adversities faster, and more productively. Teenagers may be more effective than adults in offering help for peers reluctant to express their needs. They offer understanding, reaffirmation of thoughtful presence, and practical help tips. Teenagers are able to help their peers simply by being available, talking and listening. In this way adolescents in crisis are assured that there are people willing to help.

Adolescence is considered as a time of overwhelming, stressful changes during which additional stressors (such as social isolation due to the COVID-19 pandemic) may lead to excessive worry, unhealthy eating or sleeping habits, and difficulties with attention and concentration. Sometimes the negative experiences and emotions of teenagers may be so overwhelming that the help of a professional is necessary.

\section{PROFESSIONAL HELP FOR TEENAGERS}

The results of studies on the impact of the COVID-19 pandemic on the mental health of adolescents are equi- 
vocal [46]. Some studies show no association between social isolation due to pandemic restrictions and the psychosocial well-being of young people [47]. Other empirical analyses find positive connections between fear of COVID-19, emotional reactivity, social isolation, and depressive and anxiety symptoms [48]. A high prevalence of depressive and anxiety symptoms, especially in a group of females, and young people unaware of COVID-19 risk factors, is described [49]. Also available are reports showing that an increase in the intensity of symptoms of depression and anxiety is characteristic only of teenagers who have had direct contact with someone infected with SARS-CoV-2, whereas for other adolescents a decrease in the rate of symptoms was observed after the introduction of obligatory home confinement [50]. In other words, most of the studies conducted to date underline the connection between fear of the COVID-19 pandemic, social distancing, and the mental health of adolescents. It is also stated that some of those conditions require the procurement of professional help.

As was stated previously, among professionals helping adolescents during the pandemic there are, inter alia, psychiatrists, psychologists, and social workers. Due to limited space in the article only the role of professional psychological help will be discussed. The description will be given according to the transdiagnostic model [51], enabling us to focus on complexity, and the comorbidity of mental health problems of adolescents during the pandemic. The transdiagnostic approach focuses mostly on understanding mental health difficulties with a novel conceptualization of maladaptive behavioral, emotional, cognitive, and interpersonal processes, without a concentration on traditional diagnostic boundaries. This perception helps to reflect the intricacy of the problems analyzed, and provides new, interdisciplinary ways of delivering clinical treatment [52].

Depressive problems and anxiety symptoms could be reduced with traditional therapeutic methods of proven efficacy and effectiveness. Among the most efficient and effective methods of non-medical treatment of depression are cognitive-behavioral methods [53] and computer-assisted cognitive behavioral treatment [54]. Similarly, there is an extensive amount of literature underlining the efficacy and effectiveness of cognitive behavioral models of therapy enriched by well-being enhancement methods for treatment of anxiety symptoms [55]. Therefore, ideas addressing those two problems accompanying the COVID-19 pandemic will not be discussed any further. Since the feeling of loneliness appears less often in the literature, some tips for psychological interventions aimed at decreasing the level of uneasiness accompanying solitude will be presented. Although loneliness is mostly connected to social isolation, the frequency of contacts with others is not equivalent to the subjective experience of its quality. Perceptions of social isolation and loneliness lead to massive changes in cognition (e.g., feelings and negative thoughts of self-blame and self-devaluation). An increase in the level of vigilance for social threats is observed (e.g., one negatively interprets a lack of invitation to social events, whereas receiving such an invitation is perceived as threatening). Attentional and memory biases serving as confirmations of negative self-referential thoughts appear (e.g., the individual remembers many situations pertaining to a lack of social contacts or to a poor quality of interactions with others). Changes in the behavior (mostly distance increment) of individuals follows the negative thoughts, and leads to more negative displays, interactions and affect [56].

The COVID-19 pandemic leads to many uncomfortable feelings and problems associated with the mental health and well-being of adolescents particularly in the context of involuntary social isolation [57]. In order to help young people to sustain a relatively high quality of life or to promote their well-being it is important to strengthen the structure and quality of their social network. Professionals might encourage teenagers to look at their friendships and analyze the condition of their peer interactions. Describing social connections and identifying possible problems might also be beneficial. The comparative analysis of peer relationships and interactions prior to the pandemic and during the time of social isolation may be helpful in the identification of current problems. It is crucial to see the changes in an adolescent's behavior in temporal context.

Having a wide range of rewarding activities to engage in may increase the well-being of adolescents substantially. During collaboration with psychologist or psychotherapist young people are able to identify additional sources of valued activities, and receive necessary support to implement those actions into their everyday life. The time of social isolation, and the accompanying drop in outdoor activities, may lead to an increase in the number of negative thoughts about the self and social encounters. The reappraisal of those thoughts and introduction of changes into an adolescent's behavior could help to maintain mental health.

A wide range of professional interventions are applied to mitigate the effects of social isolation and the feeling of loneliness. In general, treatments offered to lonely people provide social support, increase opportunities for social interaction or teach them to improve their social skills. There are one-on-one interventions, group therapies, and community interventions. Research shows that among the most effective techniques for reducing feeling of loneliness one-to-one cognitive behavioral interventions can be considered [58].

During cognitive behavioral therapy (CBT) sessions individuals learn to identify their negative automatic thoughts concerning others, social interactions, and isolation, and to regard these negative thoughts as hypotheses 
The functioning of adolescents during quarantine - the role of non-professional and professional support in overcoming the problem of social isolation

Funkcjonowanie nastolatków podczas kwarantanny - rola nieprofesjonalnego i profesjonalnego wsparcia w przezwyciężaniu problemu izolacji społecznej

to be verified. Treating one's negative thoughts as hypotheses rather than as facts on which to act facilitates changes in maladaptive social perceptions, and may lead to a decrease in the feeling of loneliness as a result [59]. Engagement in CBT sessions may help to reappraise negative thoughts about social encounters, and change the behavior of teenagers within the confines of their homes.

The awareness of supportive relationships may help young people to feel important, and increase the sense of meaning. Professionals can help teenagers to increase their sense of belonging within family and peer groups through analysis of their everyday actions and contacts with others. Whenever necessary, professionals should provide accurate information on the benefits and risks of social media or encourage young people to modify their activity in virtual reality.

\section{CONCLUSIONS}

As most of the research results states, social isolation caused by the COVID-19 pandemic has destructive effects on adolescents, especially since this is the developmental period of social sensitivity. Teenagers are prone to many negative effects of social restrictions, including feelings of uncertainty, boredom, exhaustion, anxiety, emotional disturbance, sadness, depression, nervousness, and anger. A deterioration in school performance, irritability, insomnia, and cognitive problems (especially in the area of attention and memory) are also reported in the literature. Since the consequences of the isolation of adolescents are major, wide-ranging, and long-lasting, it is essential to provide as much help as possible. Parents and caregivers should offer their offspring clear and sufficient information on COVID-19, and its accompanying features. They may encourage children to stay in touch with their friends, and engage in directed communication in social media (as opposed to its passive use). Finding the time for face-to-face communication and mutual activities with teenage offspring could help to prevent boredom, and increase their well-being. Teachers and resilient peers are also able to help people under 18 years of age to cope with the psychosocial effects of the pandemic. They can encourage adolescents to plan their own activity, take some responsibility for their actions, engage in helping others, etc. In this way teenagers have opportunities to increase their own resilience. Providing young people with phone numbers for support lines, and orga- nizing self-help interventions including bibliotherapy or computerized programs based on CBT therapy, might be beneficial. Offering help in arranging a meeting with a professional when necessary is also useful.

Professional help offered to teenagers during the social isolation due to the COVID-19 pandemic includes the recognition of the most detrimental problems, and contributes to an increase in the level of well-being. It has been proved that most effective are interventions aimed at the modification of maladaptive social cognition. Cognitive behavioral therapy is one such type of intervention. CBT therapy educates individuals to identify their negative thoughts, change maladaptive social perceptions, and engage in different types of behaviors. Psychotherapists can help adolescents to acquire knowledge and understanding of the differences between the active and passive use of social media, elaborate new behaviors within the confines of the home setting, or maintain a routine, which are also helpful in sustaining well-being.

Social relationships are critical to the maintenance of health and well-being. Loneliness has been linked to higher levels of stress, and increased risk of health problems. A lack of social relationships and major problems observed in peer interactions have negative impacts on the development of the structure of the brain. Social assistance offered both by caregivers and professionals helps adolescents to cope more effectively with high levels of stress. Social support is also associated with feelings of mastery, and increased quality of life. Thus, by increasing the number of social interactions, relationships, care and support experienced by socially isolated adolescents could help them avoid potential harms caused by cognitive impairments and feelings of loneliness.

It is worth noting that this article focuses mostly on the negative effects of the COVID-19 pandemic on the psychosocial functioning and mental health of adolescents. At the same time, some people report better functioning away from social crowds or at least do not declare any changes in their level of well-being. It is hypothesized that this result is due to a higher level of resilience, or withdrawal of threatening social cues, but that subject needs to be addressed more systematically. For reasons of limited space in the article, this aspect of teenage functioning during social isolation in the pandemic was not addressed here. 
Absent.

Financial support

Absent.

\section{References}

1. Brooks SK, Webster RK, Smith LE, Woodland L, Wessely S, Greenberg N, et al. The psychological impact of quarantine and how to reduce it: rapid review of the evidence. Lancet 2020; 395: 912-920.

2. Pan KY, Kok AAL, Eikelenboom M, Horsfall M, Jörg F, Luteijn RA, et al. The mental health impact of the COVID-19 pandemic on people with and without depressive, anxiety, or obsessive-compulsive disorders: a longitudinal study of three Dutch case-control cohorts. Lancet Psych 2020. DOI: 10.1016/S2215-0366(20)30491-0.

3. Khan KS, Mamun MA, Griffiths MD, Ullah I. The mental health impact of the COVID-19 pandemic across different cohorts. Int J Ment Health Addict 2020. DOI: 10.1007/s11469-020-00367-0.

4. Stieger S, Lewetz D, Swami V. Emotional well-being under conditions of lockdown: An experience sampling study in Austria during the COVID-19 pandemic. J Happiness Stud 2021. DOI: 10.1007/s10902-020-00337-2.

5. Gloster AT, Lamnisos D, Lubenko J, Presti G, Squatrito V, et al. Impact of COVID-19 pandemic on mental health: An international study. PLOS ONE 2020, 15. DOI: 10.1371/journal.pone.0244809.

6. Tso WWY, Wong RS, Tung KTS, Rao N, Fu KW, et al. Vulnerability and resilience in children during the COVID-19 pandemic. Eur Child Adolesc Psychiatry 2020. DOI: 10.1007/s00787-020-01680-8.

7. Dvorsky MR, Breaux R, Becker SP. Finding ordinary magic in extraordinary times: child and adolescent resilience during the COVID-19 pandemic. Eur Child Adolesc Psychiatr 2020. DOI: 10.1007/s00787-020-01583-8.

8. Figueiredo CS, Sandre PC, Portugal LCL, Mázala-de-Oliveira T, Chagas LS, Raony Í, et al. COVID-19 pandemic impact on children and adolescents' mental health: Biological, environmental, and social factors. Prog Neur Pharm Biol Psych 2020. DOI: $10.1016 /$ j.pnpbp.2020.110171.

9. Ghosh R, Dubey MJ, Chatterjee S, Dubey S. Impact of COVID-19 on children: special focus on the psychosocial aspect. Minerva Pediatr 2020; 72: 226-235.

10. Lee J. Mental health effects of school closures during COVID-19. Lancet Child Adolesc Health 2020. DOI: 10.1016/S23524642(20)30109-7.

11. Flannery JE, Giuliani NR, Flournoy JC, Pfeifer JH. Neurodevelopmental changes across adolescence in viewing and labeling dynamic peer emotions. Dev CognNeurosci 2017; 25: 113-127.

12. Konrad K, Firk C, Uhlhaas PJ. Brain development during adolescence: neuroscientific insights into this developmental period. DtschArztebl Int 2013; 110: 425-431.

13. Blakemore SJ, Choudhury S. Development of the adolescent brain: implications for executive function and social cognition. J Child Psychol Psych Allied Disc 2006; 47: 296-312.

14. Blakemore SJ. The social brain in adolescence. Nature reviews. Neurosc 2008; 9: 67-77.

15. Christie D, Viner R. ABC of adolescence. Adolescent development. BMJ 2005; 330: 301-304.

16. Blakemore SJ, Mills KL. Is adolescence a sensitive period for sociocultural processing? Annu Rev Psychol 2014; 65: 187-207.

17. Boivin M, Vitaro F, Gagnon V. A reassessment of the self-perceptionprofile for children: Factor structure, reliability, and convergent validity of a French version among second through sixth grade children. Int J Bevav Develop 1992; 15: 275-290.

18. Laible DJ, Carlo G. The differential relations of maternal and paternal supprot and control to adolescent social competence, self-worth, and sympathy. J Adolesc Res 2004; 19: 759-782.

19. Molloy LE, Ram N, Gest SD. The storm and stress (or calm) of each adolescent self-concepts: Within - and between - subjects variability. Develop Psychol 2011; 47: 1589-1607.

20. Pickhardt C. Surviving your child's adolescence. How to understand, and even enjoy, the rocky road to independence. San Francisco: Jossey-Bass A Wiley Imprint; 2013.

21. Chen F, Zheng D, Liu J, Gong Y, Lou D. Depression and anxiety among adolescents during COVID-19: a cross-sectional study. Brain BehavImmun 2020; 88: 36-38.

22. Saurabh K, Ranjan S. Compilance and impact of quarantine in children and adolescents due to Covid-19 pandemic. Indian J Pediatr 2020; 87: 532-536.

23. Raony I, de Figueiredo CS, Pandolfo P, Giestal-de-Araujo E, Oliveira-Silva BP, Savino W. Psycho-neuroendocrine-immune interactions in COVID-19: potential impacts on mental health. Front Immunol 2020. DOI: 10.3389/fimmu.2020.01170.

24. Rogers JP, Chesney E, Oliver D, Pollak TA, McGuire P, Fusar-Poli P, et al. Psychiatric and neuropsychiatric presentations associated with severe coronavirus infections: a systematic review and meta-analysis with comparison to the COVID-19 pandemic. Lancet Psychiatr 2020; 7: 611-627.

25. Pietrabissa G, Simpson SG. Psychological consequences of social isolation during COVID-19 outbreak. Front Psychol 2020. DOI: $10.3389 /$ fpsyg.2020.02201.

26. Imran N, Zeshan M, Pervaiz Z. Mental health considerations for children \& adolescents in COVID-19 pandemic. Pak J Med Sci 2020; 36: 67-72.

27. Frith CD, Frith U. Social cognition in humans.Curr Biol 2007; 17: 724-732.

28. Mills KL, Lalonde F, Clasen LS, Giedd JN, Blakemore SJ. Developmental changes in the structure of the social brain in late childhood and adolescence. Soc Cogn Affect Neurosci 2014; 9: 123-131. 
The functioning of adolescents during quarantine - the role of non-professional and professional support in overcoming the problem of social isolation

Funkcjonowanie nastolatków podczas kwarantanny - rola nieprofesjonalnego i profesjonalnego wsparcia w przezwyciężaniu problemu izolacji społecznej

29. Platt B, Kadosh CK, Lau JYF. The role of peer rejection in adolescent depression. Depress Anxiety 2013; 30: 809-821.

30. van Haremelen AL, Kievit RA, Ioannidis K, Neufeld S, Jones PB, Bullmore E, et al. Adolescent friendships predict later resilient functioning across psychosocial domains in a healthy community cohort. Psychol Med 2017; 47: 3212-3222.

31. Kaba F, Lewis A, Glowa-Kollisch S, Hadler J, Lee D, Alper H, et al. Solitary confinement and risk of self-harm among jail inmates. Am J Public Health 2014; 104: 442-447.

32. Tomova I, Wang K, Thompson T, Matthews G, Takahashi A, Tye K, Saxe R. The need to connect: acute social isolation causes neuronal craving responses similar to hunger. bioRxiv 2020. DOI: 10.1101/2020.03.25.006643.

33. Orben A, Tomova L, Blakemore SJ. The effects of social deprivation on adolescent development and mental health. Lancet Child Adolesc Health 2020; 4: 634-640.

34. Pigaiani Y, Zoccante L, Zocca A, Arzenton A, Menegolli M, et al. Adolescent lifestyle behaviors, coping strategies and subjective wellbeing during the COVID-19 pandemic: An online student survey. Healthcare (Basel) 2020. DOI: 10.3390/healthcare8040472.

35. Joyce S, Shand F, Tighe J, Laurent SJ, Bryant RA, et al. Road to resilience: A systematic review and meta-analysis of resilience training programmes and interventions. BMJ Open 2018. DOI: 10.1136/bmjopen-2017-017858.

36. Masten A. Ordinary magic. Resilience processes in development. Am Psychol 2001; 56: 227-238.

37. Xie X, Xue Q, Zhou Y, Zhu K, Liu Q, et al. Mental health status among children in home confinement during the coronavirus disease 2019 outbreak in Hubei Province, China. JAMA Pediatr 2020; 174: 898-900.

38. Verduyn P, Ybarra O, Résibois M, Jonides J, Kross E. Do social network sites enhance or undermine subjective well-being? A critical review. Soc Issues Policy Rev 2017; 11: 274-302.

39. Hill N, Gayle L. Engaging parents and families to support the recovery of districts and schools. Available at https:// annenberg.brown.edu/sites/default/files/EdResearch_for_Recovery_Brief_12.pdf (Accessed: 08.04.2021).

40. Thompson A, Darwich L, Bartlett L. Not remotely familiar: How COVID-19 is reshaping teachers' work and the implications for teacher education. Northwest J Teacher Educ 2020. DOI: 10.15760/nwjte.2020.15.2.2.

41. Jones AL, Kessler MA. Teachers' emotion and identity work during a pandemic. Front. Educ. 2020. DOI: 10.3389/ feduc. 2020.583775

42. Kaup S, Jain R, Shivalli S, Pandey S, Kaup S. Sustaining academics during COVID-19 pandemic: The role of online teaching-learning. Indian J Ophthalmol 2020; 68: 1220-1221.

43. Agarwal P, Malik N. Teachers roles and responsibility in relation to COVID-19 pandemic. EasyChair Preprint 4912. Available at: file://C:/Users/admin/Downloads/EasyChair-Preprint-4912.pdf (Accessed: 06.05.2021).

44. Buchner A, Majchrzak M, Wierzbicka M. Distance educatioin during pandemic. Research report. Available at: file://C:/Users/admin/Downloads/Distance-education-in-Poland-during-pandemic.pdf.pdf (Accessed: 06.05.2021).

45. Stadtfeld C, Vörös A, Elmer T, Boda Z, Raabe IJ. Integration in emerging social networks explains academic failure and success. Proceedings of the National Academy of Sciences 2019; 116: 792-797.

46. Octavius GS, Silviani FR, Lesmandjaja A, Angelina, Juliansen A. Impact of COVID-19 on adolescents' mental health: a systematic review. Middle East Curr Psychiatry 2020. DOI: 10.1186/s43045-020-00075-4.

47. Oosterhoff B, Palmer CA, Wilson J, Shook N. Adolescents' motivations to engage in social distancing during the COVID-19 pandemic: associations with mental and social health. J Adolesc Health 2020; 67: 179-185.

48. Seçer İ, Ulaş S. An investigation of the effect of COVID-19 on OCD in youth in the context of emotional reactivity, experiential avoidance, depression and anxiety. Int J Ment Heal Addicit 2020. doi.org/10.1007/s11469-020-00322-z.

49. Jiang S, Li Z, Zhang G, Lei L, Zhao W, Guo C, et al. Prevalence and socio-demographic correlates of psychological health problems in Chinese adolescents during the outbreak of COVID-19. Eur Child Adolesc Psychiatr 2020; 29: 749-758.

50. Qu M, Yang K, Cao Y, Si T, Wang X, Xiu MH, et al. Mental health status of adolescents after family confinement during the COVID-19 outbreak. Lancet 2020. DOI: 10.2139/ssrn.3594586.

51. Harvey AG, Watkins E, Mansell W, Shafran R (eds.). Cognitive behavioural processes across psychological disorders: a transdiagnostic approach to research and treatment. Oxford: Oxford University Press; 2004.

52. Dalgleish T, Black M, Johnston D, Bevan A. Transdiagnostic approaches to mental health problems: current status and future directions. J Cons Clin Psychol 2020; 88: 179-195.

53. American Psychiatric Association. Practice guideline for the treatment of patients with major depressive disorder. Third edition. 2010. Available at: https://www.umhealthpartners.com/wp-content/uploads/2016/10/DepressionAPA.pdf (Accessed: 12.04.2021).

54. Thase ME, Wright JH, Eells TD, Barrett MS, Wisniewski SR, Balasubramani GK, et al. Improving the Efficiency of Psychotherapy for Depression: Computer-Assisted Versus Standard CBT. Am J Psychiatry 2018; 175: $242-250$.

55. Widnall E, Price A, Trompetter H, Dunn BD. Routine cognitive behavioural therapy for anxiety and depression is more effective at repairing symptoms of psychopathology than enhancing wellbeing. CognTher Res 2020; 44: 28-39.

56. Cacioppo JT, Hawkley LC. Perceived social isolation and cognition. Trends Cogn Sci 2009; 13: 447-454.

57. Loades ME, Chatburn E, Higson-Sweeney N, Reynolds S, Shafran R, Brigden A, et al. Rapid systematic review: The impact of social isolation and loneliness on the mental health of children and adolescents in the context of COVID-19. J Am Acad Child Adolesc Psychiatry 2020; 59: 1218-1239.

58. Cacioppo S, Grippo AJ, London S, Goossens S, Goossens L, Cacioppo JT. Loneliness: Clinical import and interventions. Perspect Psychol Sci 2015; 10: 238-249.

59. Masi CM, Chen HY, Hawkley LC, Cacioppo JT. A meta-analysis of interventions to reduce loneliness. Pers Soc Psychol Rev 2011; 15: 219-266. 